\title{
Potensi Produksi Kacang Tanah Lokal Situraja
}

\author{
DOI 10.18196/pt.2016.055.37-45
}

Try Zulchi

Balai Besar Bioteknologi dan Sumber Daya Genetik Pertanian, Jl. Tentara Pelajar No. 3A,

Bogor 16111; Email : tryzulchi@yahoo.co.id

\begin{abstract}
ABSTRAK
Di daerah Sumedang, varietas lokal kacang tanah DM Situraja mempunyai potensi yang besar dan menunjukkan peningkatan produksi yang tinggi. Hal ini dapat menunjang pengembangan agribisnis kacang tanah yang ada di Kabupaten Sumedang. Maka perlunya untuk mengetahui potensi produksi kacang tanah Lokal varietas DM Situraja spesifik lokasi di Kabupaten Sumedang. Kegiatan penelitian ini dilakukan di Sumedang pada bulan April -juli menggunakan rancangan percobaan yaitu Rancangan Acak Kelompok yang diulang 4 kali. Analisa data menggunakan program SPSS versi 16 dan uji lanjut dengan Uji Beda Nyata Terkecil (BNT) dengan taraf kesalahan 5\%. Hasil penelitian menunjukkan bahwa morfologi kacang tanah Situraja memiliki tipe tumbuh tegak, berbiji 2 dan berat 40 - 55 g per 100 biji, panen berumur 90 hari dan potensi produksi 3,02 t/ha. Kandungan kadar lemak sebesar 45\%, kadar protein yang relatif tinggi sebesar 28\% dan mempunyai rasa manis renyah. Hasil produksi varietas lokal DM Situraja yang maksimal akibat interaksi varietas dengan lingkungan.

Kata Kunci: Kacang tanah, Varietas lokal Situraja, Umur genjah, Produksi tinggi, Mutu fungsional
\end{abstract}

\begin{abstract}
In Sumedang, local variety of groundnut DM Situraja has a great potential and showed increasing production rates. This support the agribusiness development of groundnut in Sumedang District and surrounding areas. The objective of this experiment was to determine production potential of local variety groundnut Situraja especially in Sumedang. This research was arranged in a randomized complete block design whereas each treatment was replicated 4 times. The data were analyzed using SPSS version 16 and treatment means were separated using LSD (Least Significant Difference) with $5 \%$ error level. The results indicated that morphology of Situraja variety had an upright growth habit, rod-shaped and green purplefish, 2-seeded, and seed weight 40-55g for 100 seeds, maturing age of 90 days, and the production potential 3,02 t/ha. The content of oil was $45 \%$, with a relatively high protein content of $28 \%$ and crunchy sweet taste. High productivity of DM Situraja local variety was resulted by interaction between variety and spesific enviroment.
\end{abstract}

Keywords: Groundnut, Situraja Local Variety, Early Mature; High Production, Functional Quality

\section{PENDAHULUAN}

Produktivitas kacang tanah di Indonesia selama 17 tahun terakhir (1986 - 2003) hanya mengalami sedikit peningkatan, yaitu dari kisaran 0,7 ton/ha menjadi 1,2 ton/ha biji kering (Kasno et al., 2006). Masih rendahnya produktivitas tersebut antara lain diakibatkan oleh lingkungan cekaman biotik, abiotik dan tanggap varietas terhadap lingkungan (Kasno, 2009, Purnomo et al., 2006; Baehaki dan Wicaksana, 2005, Norden et al., 1982), bahkan teknologi atau cara budidaya belum memadai (Ditjen Produksi Tampan, 2001).

Ada beberapa varietas unggul yang berkembang baik di Jawa Barat yaitu kacang tanah varietas Singa, Kancil dan Garuda serta ada varietas lokal Situraja di Kabupaten Sumedang dan sekitarnya. Luasan tanam kacang tanah sebesar 49124 ha dengan rata-rata produktivitas mencapai 1,08 ton/ha telah menempatkan Propinsi Jawa Barat sebagai produsen kacang tanah di urutan ke-3 dalam skala nasional (Hidajat et al., 2000).

Di daerah Sumedang terdapat varietas lokal kacang tanah (DM Situraja) mempunyai potensi yang besar dan menunjukkan peningkatan produksi yang tinggi. Tabel 1 menunjukkan 
Tabel 1. Luas Tanam dan Produksi Kacang Tanah di Kabupaten Sumedang

\begin{tabular}{lllllll}
\hline N0 & 2004 & 2005 & 2006 & 2007 & 2008 & Rata-rata \\
\hline 1. Luas (Ha) & 4752 & 4775 & 4908 & 4675 & 5190 & 4860 \\
2. Produksi (Ton) & 5940 & 6300 & 6562 & 6217 & 7191 & 6442 \\
3. Produktifitas (t/ha) & 1.25 & 1.32 & 1.34 & 1.33 & 1.39 & 1.32 \\
4. \% Peningkatan luas tanam & - & 0.48 & 2.79 & -4.75 & 11.02 & 5.16 \\
5. \% Peningkatan produksi & - & 6.06 & 4.16 & -5.26 & 15.67 & 2.38 \\
\hline
\end{tabular}

produksi kacang tanah yang mengalami peningkatan dari tahun 2004 sampai 2008 yaitu dari 9504 ton menjadi 11106 ton. Seiring makin berkembangnya produksi, telah didukung kebijakan pemerintah daerah setempat yang membantu pengembangan produksi kacang tanah Lokal Situraja melalui pendanaan APBD Kabupaten Sumedang kepada Kelompok tani setempat (Tim Pelepas Varietas, 2009).

Umumnya penanaman kacang tanah di lahan kering dan tadah hujan dan lahan sawah irigasi setelah padi. Waktu penanaman pada bulan Maret - April dan Nopember Desember sehingga panen kacang tanah terbesar terjadi pada bulan Mei sampai Juli dan atau Pebruari sampai Maret (Ditjen Produksi Tampan, 2001). Namun demikian kebutuhan bahan baku biji kering kacang tanah sebanyak 30 - 40 ton/bulan belum memenuhi permintaan perusahaan swasta pengolah kacang tanah di Sumedang. Hal tersebut dapat menjadi rentan pada penyediaan bahan baku untuk industri pengolahan hasil sehingga dapat menyebabkan fluktuasi harga yang tajam dan dapat merugikan petani (Tim Pelepasan Varietas Kacang Tanah, 2009).
Pada saat ini masih terjadi fluktuasi produksi dalam menjamin kesinambungan ketersediaan kacang tanah skala industri dan nasional. Disisi lain kebutuhan industri pengolahan membutuhkan bahan baku kacang tanah yang besar. Ketersediaan bahan baku tersebut dapat dipenuhi dengan produksi dari varietas unggul nasional dan unggul wilayah (Baehaki dan Wicaksana, 2005). Namun kurangnya pemahaman petani mengenai produksi kacang tanah lokal menyebabkan petani masih ragu akan potensi dari kacang tanah lokal tersebut bila ditanam di lahan mereka. Salah satu upaya dalam mengembangkan produksi kacang tanah lokal Situraja yang dilaksanakan di beberapa Desa di kecamatan Sumedang adalah dengan memahami karakter tanaman tersebut. Hal ini perlu dikaji untuk mengetahui karakter potensi produksi kacang tanah Varietas Lokal Situraja Sumedang dibanding varietas unggul lainnya.

\section{BAHAN DAN METODE}

Kegiatan penelitian tanaman kacang tanah Situraja dilakukan di Desa Situraja, Situraja Utara, Cilopang dan Ambit pada musim kering tahun 2009. Disamping itu juga ditanam varietas unggul yaitu varietas Bison, Kancil, 
Singa, dan Turangga. Penanaman kacang tanah dengan membuat petak percobaan sebesar 2,5 $\mathrm{x}$ $2,5 \mathrm{~m}^{2}$ atau areal penanaman seluas 0,1 ha $(1$ biji/lubang) dengan jarak antar baris $40 \mathrm{~cm}$ dan jarak antar tanaman $20 \mathrm{~cm}$. Dosis pemupukan sebesar $50 \mathrm{~kg}$ urea, $100 \mathrm{~kg}$ SP36, $50 \mathrm{~kg} \mathrm{KCl}$ per hektar diberikan secara larikan. Penambahan unsur hara kalsium (Ca/dolosit) $200 \mathrm{~kg} / \mathrm{ha}$ diberikan 20 - 25 hari setelah tanam.

Penyiangan pada 3 dan 7 minggu setelah tanam. Penyemprotan hama dan penyakit dilakukan secara proporsional. Analisa kimia kadar lemak dan protein dilakukan di BB Pasca Panen Bogor.

Rancangan percobaan yang digunakan yaitu Rancangan acak kelompok yang diulang 4 kali. Analisa data menggunakan program SPSS versi 16 dan uji lanjut dengan uji BNT (Beda Nyata Terkecil) dengan taraf kesalahan 5\%. Karakter yang diamati adalah karakter tipe tumbuh, umur berbunga, tinggi tanaman, umur panen, jumlah polong per tanaman, banyaknya biji per polong, bobot 100 biji, warna kulit ari biji, dan karakter mutu fungsional diamati yaitu kadar lemak (Metode Soxhlet) dan kadar protein (Metode Kjedahl).

\section{HASIL DAN PEMBAHASAN}

\section{Karakter Morfologi}

Karakterisasi merupakan identifikasi (deskripsi) informasi mengenai sifat-sifat yang dimiliki oleh suatu individu (spesies) tersebut. Sifat yang dikarakterisasi dari macam-macam varietas unggul kacang tanah yang ditanam adalah karakter morfologinya. Hasil karakterisasi tanaman kacang tanah termasuk tanaman semusim (annual crop) yang memiliki susunan tajuk utama terdiri dari daun, batang, bunga, polong dan biji. Pada tabel 2 menunjukkan bahwa tanaman kacang tanah mempunyai batang bertipe tegak dan tinggi tanaman bervariasi antara $30-78 \mathrm{~cm}$. Warna bunga kuning dengan guratan mahkota bunga berwarna merah. Jumlah polong lebih dari 10 polong per tanaman dan tiap polong berisi dua

Tabel 2. Morfologi Tanaman Kacang Tanah Lokal Situraja, Bison, Kancil, Singa, dan Turangga

\begin{tabular}{|c|c|c|c|c|c|c|}
\hline No & Karakter & DM Situraja & Bison & Kancil & Singa & Turangga \\
\hline 1. & Tipe batang utama & Tegak & Tegak & Tegak & Tegak & Tegak \\
\hline 2. & Umur berbunga (hari) & $<26$ & $28-32$ & $26-28$ & $28-31$ & $28-31$ \\
\hline 3. & Tinggi tanaman (cm) & $40-50$ & $30-70$ & $50-55$ & $50-55$ & $70-78$ \\
\hline 4. & Umur panen (hari) & $85-90$ & $90-95$ & $90-95$ & $90-95$ & $100-110$ \\
\hline 5. & $\begin{array}{l}\text { Jumlah polong per tanaman } \\
\text { (buah) }\end{array}$ & $20-30$ & $10-40$ & $15-20$ & $15-20$ & $14-20$ \\
\hline 6. & Jumlah biii per polong (buah) & $1-2$ & $1-3$ & $1-2$ & $3-4$ & $2-4$ \\
\hline 7. & Warna kulit ari biii & Rose & Rose & Rose & Rose & Rose \\
\hline 8. & Bobot 100 biii (g) & $40-55 \mathrm{~g} /$ sedang & $35-38 \mathrm{~g} /$ kecil & $35-40 \mathrm{~g} /$ kecil & $35-40 \mathrm{~g} /$ kecil & $40-50 \mathrm{~g} /$ sedang \\
\hline 9. & Toleransi abiotik dan biotik & $\begin{array}{l}\text { Toleran kekeringan, } \\
\text { spesifik lokasi (varietas } \\
\text { lokal), toleran penyakit } \\
\text { layu, toleran karat } \\
\text { daun, bercak daun dan } \\
\text { A.flavus }\end{array}$ & $\begin{array}{l}\text { Toleran naungan, } \\
\text { adaptif alfisol } \\
\text { alkalis. Agak tahan } \\
\text { karat, bercak daun } \\
\text { dan A.flavus }\end{array}$ & $\begin{array}{l}\text { Tahan klorosis, } \\
\text { tahan penyakit layu, } \\
\text { toleran karat, bercak } \\
\text { daun, tahan } \\
\text { A.flavus }\end{array}$ & $\begin{array}{l}\text { Toleran kekeringan } \\
\text { dan adaptasi luas. } \\
\text { Toleran penyakit } \\
\text { layu, bercak daun, } \\
\text { dan tahan karat }\end{array}$ & $\begin{array}{l}\text { Toleran kekeringan } \\
\text { dan naungan. tahan } \\
\text { penyakit layu, } \\
\text { toleran karat, } \\
\text { bercak daun, dan } \\
\text { A.flavus }\end{array}$ \\
\hline 10. & Tahun pelepasan & 2010 & 2004 & 2001 & 1998 & 2001 \\
\hline
\end{tabular}

Sumber: Tim Pelepas Varietas Kacang Tanah (2009), Kementan (2011) 
hingga empat (2 - 4) biji, sedangkan bobot 100 biji kisaran 35 - $55 \mathrm{~g}$ dan warna kulit ari biji yaitu rose.

\section{Respon Karakter Tanaman pada Berbagai Varietas Kacang Tanah}

Karakter tanaman kacang tanah yang digunakan berasal dari kacang tanah tipe spanish dan valencia. Adapun tipe Kacang tanah tipe spanish umumnya memiliki dua biji/ polong, sedikit berparuh, polong sedikit berpinggang dan retikulasi agak halus, umur lebih genjah, pola percabangan sequential, dan pertumbuhan tegak. Tipe valencia memiliki jumlah biji/polong tiga atau lebih, polong sedikit berpinggang dan retikulasi agak halus, pola percabangan sequential, dan tipe tumbuh tegak (Kasno dan Harnowo, 2014).

Pada Lampiran 1 menunjukkan bahwa hasil sidik ragam pada semua varietas tanaman kacang tanah mempunyai respon yang berbeda nyata. Pada karakter umur muncul bunga, jumlah polong, dan umur panen bersifat sangat nyata, sedangkan hasil produksi bersifat nyata terhadap semua varietas kacang tanah yang ditanam. Selanjutnya dari hasil sidik ragam dianalisa uji lanjut dengan pengujian Beda Nyata terkecil (BNT) dengan taraf kesalahan 5\%.

Saat berbunga tanaman kacang tanah berkisar antara 27 - 32 hari dan pola pembungaan bersifat sequential (kontinue), berbentuk bunga matahari yang berwarna kuning dan warna guratan mahkota bunga merah (Kasno, 1993). Bunga kacang tanah Situraja mulai terbentuk umur kisaran 25 - 27 hari setelah tanam (hst). Terjadi pembungaan yang efektif pada hari ke-24 sampai 45 hst, ketika bunga mekar akan muncul ginofor yang berwarna ungu yang bergerak ke dalam tanah hingga pembentukan polong.
Tabel 3. Umur Muncul Bunga (Hari) Kacang Tanah di Berbagai Lokasi Percobaan

\begin{tabular}{ll}
\hline Varietas & $\begin{array}{l}\text { Rata-rata awal } \\
\text { berbunga (hari) }\end{array}$ \\
\hline Lokal Situraja & 25 \\
Bison & $30^{* *}$ \\
Kancil & $28^{* *}$ \\
Singa & $28^{* *}$ \\
Turangga & $31^{* *}$ \\
BNT 5\% & 1,65 \\
\hline
\end{tabular}

Keterangan: ${ }^{* *}=$ berbeda sangat nyata pada $1 \%{ }^{*}=$ berbeda nyata pada $5 \%$; tn $=$ tidak berbeda nyata

Tabel 3 menunjukkan bahwa umur berbunga kacang tanah varietas Lokal Situraja lebih cepat 2 - 3 hari dibandingkan varietas unggul lainnya. Hal ini diduga tingginya konsentrasi hormon pembungaan (florigen) tanaman tersebut (Cox and Martin, 1974), hormon florigen berfungsi dalam induksi dan ekspresi pembungaan (Gardner et al., 1991) juga telah terpenuhinya tahap vegetatif dasar, yang selanjutnya fotosintat ditranslokasikan ke tahap reproduktif. Selain itu awal berbunga adanya kesesuaian varietas tersebut dengan lingkungan setempat terutama suhu dan kelembaban (Trustinah, 1993). Transisi fase vegetatif ke fase pembungaan itu bersifat komplek dan dikontrol oleh banyak gen dan berbagai lintasan pathway (Levy and Dean, 1998; Koerneneef et al., 1998). Suhu optimum pembungaan kacang tanah yaitu suhu siang hari $30{ }^{\circ} \mathrm{C}$ dan suhu malam hari $26{ }^{\circ} \mathrm{C}$ (Trustinah, 1993).

Untuk memulai pembentukan polong, ginofor akan memanjang kemudian menuju dan menembus tanah (Norden et al., 1983). Sekitar satu minggu setelah ginofor masuk ke 
dalam tanah, ujung ginofor akan membesar sampai mencapai ukuran polong maksimal pada umur 45 - 60 hari. Setelah polong mencapai ukuran maksimal maka dimulai pengisian biji polong hingga penuh, yang dimulai dari pangkal ke ujung biji pada umur 60 - 75 hari. Pada tabel 4 menunjukkan jumlah polong varietas Situraja mencapai 29 polong per tanaman yang lebih tinggi 30\% - 45\% dari varietas unggul kacang tanah lainnya. Hal ini dapat disebabkan adaptasi varietas unggul lokal dalam efektivitas serapan ketersediaan hara dan air dalam tanah saat fase pembentukan polong maksimal (Boote, et al., 1982, Nugrahaeni, 1993), kuat dan dekatnya ginofor dalam menembus tanah (Trustinah, 1993) karena pada periode tersebut pertumbuhan polong mengalami akumulasi bahan kering yang maksimum (Boote et al., 1982).

Tabel 4. Jumlah polong per tanaman kacang tanah di beberapa lokasi percobaan

\begin{tabular}{ll}
\hline Varietas & $\begin{array}{l}\text { Rata-rata } \\
\text { Jumlah polong (buah) }\end{array}$ \\
\hline Lokal Situraja & 28.75 \\
Bison & $16.00^{* *}$ \\
Kancil & $19.25^{* *}$ \\
Singa & $18.00^{* *}$ \\
Turangga & $17.75^{* *}$ \\
BNT 5\% & 1,57 \\
\hline $\begin{array}{l}\text { Keterangan:** }=\text { berbeda sangat nyata pada } 1 \% ;^{*}{ }^{*}=\text { berbeda nyata pada } 5 \% \\
\text { tn }=\text { tidak berbeda nyata }\end{array}$
\end{tabular}

Saat umur 75 sampai 90 (100) hari, perubahan morfologi di dalam dan luar kulit polong terus berlangsung hingga pematangan biji. Waktu panen terbaik adalah bila 75\% polong-polong yang ada memperlihatkan bintikbintik hitam di bagian dalam kulit (Trustinah,
1993; Sumarno dan Slamet, 1983). Pemanenan dilakukan pada umur tanaman 90 - 100 hari setelah tanam dan rendemen polong berisi lebih dari 70\%, dengan ukuran biji berukuran sedang, bobot 100 biji kisaran $40-55 \mathrm{~g}$, jumlah isi per polong sebanyak 2 biji dan jumlah polong di atas 20 polong per tanaman serta rata-rata mencapai 2,0 - 2,3 ton/ha. Biji yang besar biasanya dipakai sebagai bahan baku pangan kacang lemak rendah (Ginting, 2012).

Umur panen genjah (early maturity) merupakan salah satu prioritas tujuan program pemuliaan tanaman kacang tanah terutama di daerah pertumbuhan tanaman yang bermusim terbatas seperti musim dingin atau kering, serangan hama penyakit, dan sistem tumpangsari (Norden et al., 1982). Namun pertumbuhan dan produksi biji kacang tanah akan mengalami hambatan maka perbaikan tanaman sangat diperlukan sebagai solusi terhadap hal tersebut. Dalam hal ini varietas Situraja dirakit sebagai upaya perbaikan ketahanan pada penyakit daun baik bercak daun, karat daun dan layu bakteri sejak tahun 70-an (Tim Pelepas Varietas, 2009). Pada tabel 5 menunjukkan bahwa umur panen kacang tanah varietas Situraja lebih cepat 6 - 10 hari dibanding varietas unggul lainnya. Hal ini dimungkinkan adanya sifat karakter tanaman yang toleran atau menghindar (escape mechanism) dari cekaman biotik tersebut (Norden et al., 1982), pembungaan awal selama 12 hari telah mendorong panen yang lebih cepat dan hasil yang tinggi (Ketring et al., 1982), juga gen Dt1 pada pertumbuhan kedelai kedelai telah mengontrol waktu berbunga dan panen (Foley et al., 1986). 
Tabel 5. Umur Panen (Hari) Kacang Tanah di Beberapa Lokasi Percobaan

\begin{tabular}{ll}
\hline Varietas & $\begin{array}{l}\text { Rata-rata } \\
\text { Umur panen (hari) }\end{array}$ \\
\hline Lokal Situraja & 85 \\
Bison & $95^{* *}$ \\
Kancil & $91^{* *}$ \\
Singa & $92^{* *}$ \\
Turangga & $91^{* *}$ \\
BNT 5\% & 1,36 \\
\hline
\end{tabular}

Keterangan: ${ }^{* *}=$ berbeda sangat nyata pada $1 \% ;{ }^{*}=$ berbeda nyata pada $5 \%$; tn = tidak berbeda nyata

\section{Hasil Produksi}

Dari tabel 6 menunjukkan bahwa rata-rata produksi kacang tanah lokal dalam petakan mencapai $2.1 \mathrm{~kg} / 6,25 \mathrm{~m}^{2}$. Jika dikonversikan ke hektar dengan dikurangi sebesar 10\% maka hasil produksi kacang tanah Situraja setara 3.02 ton/ha. Kemampuan potensi produksi kacang tanah Situraja yang berkualitas baik mencapai 2,0 - 2,3 t/ha, hal ini disebabkan adanya kemampuan genetik dari varietas tersebut dalam beradaptasi dengan kondisi lingkungan setempat (Baehaki dan Wicaksana, 2005, Kasno, et al,. 2006, ), hasil maksimal kacang tanah akan diperoleh dengan menggunakan varietas spesifik lokasi seperti varietas Tuban, Demak, dan Majalengka (Kasno, 2009). Di sisi lain, pemerintah setempat telah mendukung dan memberi mediasi kerjasama petani dengan industri pengolahan kacang tanah, sehingga petani menjadi bergairah menanam kacang tanah secara kontinyu (Tim Pelepas Varietas Kacang Tanah, 2009).

Meskipun tahun 2007 luas pertanaman dan produksi mengalami penurunan sebesar $4,75 \%$ dan 5,26\% tetapi tahun 2008 luas tanam dan produksi kacang tanah meningkat menjadi 11,02\% dan 15,67\%. Bahkan Pemerintah Daerah Sumedang memberikan apresiasi yang bagus kepada petani atau kelompok tani dalam agribisnis kacang tanah Situraja (Tim Pelepas Varietas Kacang Tanah, 2009). Dukungan tersebut berupa budidaya yang intensif (teknologi), pengadaan benih bermutu yang disukai industri pengolahan, harga yang relatif stabil, dan dukungan pemerintah setempat (menghubungkan petani dengan pengusaha swasta dari hulu hingga hilir secara langsung) serta penguatan organisasi dan kelembagaan ekonomi petani (Kelompok tani dan koperasi petani). Pada tahun 2009, berdasar Surat Keputusan Kepala Dinas Pertanian Tanaman Pangan dan Hortikultura Kabupaten Sumedang dalam Penetapan Kelompok Tani untuk Peningkatan Produksi Kacang Tanah di Lahan Kering terutama varietas lokal Sumedang yaitu DM Situraja.

Tabel 6. Hasil produksi berbagai Varietas Unggul di Kabupaten Sumedang

\begin{tabular}{ll}
\hline Varietas & $\begin{array}{l}\text { Rata-rata } \\
\text { hasil produksi }\left(\mathrm{kg} / 6,25 \mathrm{~m}^{2}\right)\end{array}$ \\
\hline Lokal Situraja & 2.10 \\
Bison & $1.73^{* *}$ \\
Kancil & $1.78^{*}$ \\
Singa & $1.78^{*}$ \\
Turangga & $1.95 \mathrm{tn}$ \\
BNT 5\% & 0,24 \\
\hline
\end{tabular}

Keterangan: ${ }^{* *}=$ berbeda sangat nyata pada $1 \% ;{ }^{*}=$ berbeda nyata pada $5 \%$; $\mathrm{tn}=$ tidak berbeda nyata

\section{Karakter Mutu Fungsional}

Sifat fungsional kacang tanah diindikasikan oleh adanya kandungan senyawa protein dan 
Tabel 7. Hasil Analisis Kandungan Lemak dan Protein Kacang Tanah

\begin{tabular}{lllllll}
\hline No. & Karakter mutu gizi & $\begin{array}{l}\text { Hasil Analisis } \\
\text { DM Situraja }\end{array}$ & Bison & Kancil & Singa & Turangga \\
\hline 1 & Kadar Lemak (\%) & 45 & 44 & 50 & 43 & 47 \\
2 & Kadar Protein (\%) & 28 & 24 & 29 & 21 & 25 \\
\hline
\end{tabular}

lemak, yang berperan sangat penting terhadap kualitas produk olahannya. Umumnya biji kacang tanah mempunyai kadar lemak 41,5 $56,0 \%$ dan protein $21,0-34,0 \%$. Dengan kadar lemak yang tinggi, kacang tanah dapat digunakan sebagai bahan baku minyak nabati. Bungkil kacang tanah sebagai produk samping industri minyak goreng juga dapat dimanfaatkan sebagai bahan pakan ternak. Protein nabati dapat dihasilkan dalam waktu yang relatif pendek dan harganya lebih murah, khususnya dari kacang tanah (Santosa, 2010 dan Ginting, 2012). Konsumen yang mengonsumsi kacang tanah memiliki risiko yang rendah terjangkit penyakit jantung karena kacang tanah mempunyai kandungan gizi (protein, asam lemak, niasin, magnesium, vitamin $\mathrm{C}$ dan E, mangan, khromium, fosfor, dan lainnya) dalam jumlah yang memadai.

Dari Tabel 7 menunjukkan hasil analisis kandungan dan komposisi fungsional kacang tanah Situraja memiliki kadar kandungan lemak yang relatif tinggi sebesar $45 \%$ dan juga kadar protein yang relatif tinggi sebesar 28\% namun lebih rendah dari varietas Kancil, dan mempunyai rasa yang manis renyah. Adanya perbedaan kandungan fungsional ini dimiliki oleh masing-masing varietas akibat kemampuan yang berbeda dalam biosintesis trigliserida dan asam amino, karena memiliki komposisi enzim yang berbeda (Widowati et al, 1999). Dengan komposisi enzim ini telah mempengaruhi komposisi dan kadar pada asam lemak dan asam amino yang dihasilkan oleh masing-masing varietas tersebut (Norden et al., 1982).

Dengan pengetahuan kadar lemak dan protein telah memberikan nilai cita rasa kesukaaan dari konsumen dan industri pengolahan kacang tanah (Susila, 2010; Ginting, 2012). Kadar protein kacang tanah tersebut telah memiliki kadar yang lebih tinggi daripada telur, susu, dan daging sapi. Bahkan bila mengkonsumsi biji kacang tanah maka energi yang dihasilkan bersifat kontinyu dan stabil akibat kandungan fungsional biji tersebut. Komposisi asam lemak produk pertanian berperan sangat penting dalam penyimpanan atau daya simpan, nutrisi, dan cita rasa (Susila, 2010). Untuk menghambat proses kerusakan hidrolitik biji dapat diupayakan dengan mengurangi serendah mungkin kadar air biji dan kondisi penyimpanan yang terkontrol agar dapat menghindari pencemaran oleh bakteri dan jamur. Biji kacang tanah yang sudah masak sangat sedikit mengandung asam linolenat penyebab reversion flavor (Susila, 2010).

\section{SIMPULAN}

Kacang tanah DM Situraja Kabupaten Sumedang memiliki tipe tumbuh tegak, berbiji 2, warna biji rose dan bobot sedang per 100 biji, berumur genjah dan potensi produksi tinggi 3.02 ton/ha dibanding varietas unggul. Kandungan lemak dan protein yang relatif 
tinggi serta rasa manis renyah.

Varietas spesifik lokasi (wilayah) mempunyai

hasil yang produktif akibat interaksi varietas

dengan lingkungan seperti varietas DM Situraja

Sumedang.

\section{UCAPAN TERIMA KASIH}

Penulis ucapkan terima kasih kepada Ibu Sri Tuti Rais dan Tim Pelepas Varietas Kacang

Tanah Situraja atas informasi data, kerjasama, dan saran-sarannya dalam membantu tersusunnya karya ilmiah ini.

\section{DAFTAR PUSTAKA}

Baehaki, A dan N. Wicaksana, 2005. Interaksi Genotip dan lingkungan, Adaptabilitas, dan Stabilitas Hasil dalam Pengembangan Tanaman Varietas Unggul di Inodnesia. Zuriat 16(1):50-55

Boote, K.J, J.R. Stansell, A.M. Schubert, and J.F. Stone. 1982. Irrigation, water use, and water relations. 164 - 205p. In Pattee, H.E. and C.T. Young (Eds.). Peanut Science and Technology. America Peanut Research and Education Soc, Inc. Texas

Cox, F. R. and C. K. Martin, 1974. Effect of Temperature on Time from Planting to Flowering in Virginia Type Peanuts (Arachis hypogaea L.). Peanut Science 1(2); 222-230

Direktorat Jenderal Produksi Tanaman Pangan, 2001. Pedoman Umum Pengembangan Sistem dan Perusahaan Agribisnis Kacang Tanah 2001 - 2004. Direktorat Jenderal Produksi Tanaman Pangan Departemen Pertanian. Jakarta

Direktorat Kacang-Kacangan dan Umbi-Umbian, 2002. Prospek Agribisnis Kacang Tanah. Direktorat Jenderal Bina Produksi Tanaman Pangan. Departemen Pertanian. Jakarta.

Foley, T.C, J.H. Orf, and J.W. Lambert. 1986. Performance of realted determine and intermediate soybean lines. Crop Sci. 26:5 - 8.

Ginting, E. 2012. Kacang Tanah Lemak Rendah. Sinar Tani Edisi 2127 Maret 2012 No. 3449 Tahun XLII. Jakarta.

Hidajat, J. R., Kartaatmadja, S. dan Rais,S.A. 2000. Teknologi Produksi Benih Kacang Tanah. Pusat Penelitian Pengembangan Tanaman Pangan Bogor. Balai Penelitian Pengembangan Pertanian. Bogor.

Kasno, A. 1993. Pengembangan Varietas Kacang Tanah. Dalam A.Kasno, A. Winarto, dan Sunardi (Eds.) Monograf Balittan Malang No. 12. Balai Penelitian Tanaman Pangan Malang. Malang.

Kasno, A, Trustinah, J. Purnomo dan N. Nugraheni. 2006. Seleksi Simultan Beberapa Karakter Pada Populasi Galur Homosigot Kacang Tanah. Dalam Prosiding Peningkataan Produksi
Kacang-kacangan dan Umbi-Umbian Mendukung Kemandirian Pangan. Pusat Penelitian dan Pengembangan Tanaman Pangan. Bogor

Kasno, A. 2009. Varietas Spesifik Lokasi untuk Maksimalisasi Produktivitas Kacang Tanah. Buletin Palawija No.18.

Kasno, A dan D. Harnowo. 2014. Karakteristik Varietas Unggul Kacang Tanah dan Adopsinya oleh Petani. Iptek tanaman pangan $9(1)$

http://pangan.litbang.pertanian.go.id/files/02-lptek012014Astanto.pdf tglakses 20 Januari 2015

Kementan. 2011. Deskripsi Varietas Unggul Kacang-kacangan dan Umbi-umbian. Balitkabi. hal 75-105

Ketring, D.L, R.H. Brown, G.A. Sullivan, and B.B. Johnson. 1982. Growth Physiology. 411 - 457 p. In Pattee, H.E. and C.T. Young (Eds.). Peanut Science and Technology. America Peanut Research and Education Soc, Inc. Texas.

Koerneneef, M, C. Aloso-Balnco, A.j.M. Peters, and W. Soppe. 1998. Genetic control of flowering time in Arabidopsis. Annu. Rev. Plant Physiol. Plant Mol. Biol. 49: 345 -370

Levy, Y. Y and C. Dean. 1998. The transition to flowering. Palnt Cell 10:1973-1989

Norden, A.J, O. D. Smith, and D.W. Gorbet. 1982. Breeding of the Cultivated Peanut. 95 - 122 p. In Pattee, H.E. and C.T. Young (Eds.). Peanut Science and Technology. America Peanut Research and Education Soc, Inc. Texas.

Nugrahaeni, N. 1993. Pemuliaan Kacang Tanah untuk Ketahanan terhadap Penyakit dan Cekaman Lingkungan Fisik. Dalam Monograf Balai Tanaman Pangan Malang No. 12. Balai Penelitian Tanaman Pangan Malang. Malang.

Purnomo, J, Trustinah dan Nugrahaeni, N. 2006. Tingkat Kehilangan Hasil kacang Tanah Tipe Spanish dan Valencia Akibat Kekeringan. Dalam Prosiding Peningkataan Produksi Kacangkacangan dan Umbi-Umbian Mendukung Kemandirian Pangan. Pusat Penelitian dan Pengembangan Tanaman Pangan. Bogor.

Santosa, B.A.S, 2010. Inovasi Teknologi Defatting : Peluang Peningkatan Diversifikasi Produk Kacang Tanah Dalam Industri Pertanian. Pengembangan Inovasi Pertanian 3 (3) : 199-211

Sumarno dan Slamet, P. 1993. Fisiologi dan Pertumbuhan Kacang Tanah. Dalam Monograf Balai Tanaman Pangan Malang nomor 12. Balai Penelitian Tanaman Pangan Malang. Malang.

Tasma, I.M, D. Satyawan, A. Warsun, M. Yunus, and B. Santosa. 2011. Philogenetic and Maturity Analyses of Sixty Soybean genotypes usedfor DNA Marker Development of Early maturity Quantitive Trait Loci in Soybean. Jurnal Agrobiogen 7 (1): $37-46$

Tim Pelepas Varietas Kacang Tanah. 2009. Pelepasan Kacang Tanah Lokal Situraja DM-1 Asal Kabupaten Sumedang. Balai Pengawasan dan Sertifikasi Benih Tanaman Pangan dan Hortikultura Provinsi Jawa Barat. Bandung.

Trustinah, 1993. Biologi Kacang Tanah. Dalam Monograf Balai Tanaman Pangan Malang No. 12. Balai Penelitian Tanaman Pangan Malang. Malang.

Widowati, S, S.K. S. Wijaya, dan L. Sukarno. 1999. Komposisi Asam Lemak dari Berbagai Varietas dan Galur Kedelai Indonesia. Penelitian Pertanian Tanaman Pangan 18 (2): 23- 28 


\section{Lampiran 1. Sidik jari berbagai varietas kacang tanah di Kabupaten Sumedang}

\begin{tabular}{lcllll}
\hline $\begin{array}{l}\text { Sumber keragaman } \\
\text { Perlakuan }\end{array}$ & $\mathrm{db}$ & $\begin{array}{l}\text { Kuadrat Tengah } \\
\text { Umur berbunga }\end{array}$ & Jumlah polong & Umur panen & Hasil produksi \\
\hline Varietas & 4 & $30.8^{* *}$ & $102.175^{* *}$ & $50.075^{* *}$ & $0.098^{*}$ \\
Galat percobaan & 15 & 1.20 & 1.083 & 0.817 & 0.025 \\
Umum & 19 & & & & \\
\hline
\end{tabular}

\section{Lampiran 2. Letak geografis dan topografi Kabupaten Sumedang}

Letak Geografis dan Luas Wilayah

Kabupaten Sumedang terletak antara 644' - 70॰83' Lintang Selatan dan 107'21' - 108²1' Bujur Timur, dengan Luas Wilayah 152.220 Ha yang terdiri dari 26 kecamatan dengan 272 desa dan 7 kelurahan. Kabupaten Sumedang merupakan daerah berbukit dan gunung dengan ketinggian tempat antara $25 \mathrm{~m}$ - $1667 \mathrm{~m}$ di atas permukaan laut. Sebagian besar Wilayah Sumedang adalah pegunungan, kecuali di sebagian kecil wilayah utara berupa dataran rendah. Gunung Tampomas (1.667 m) berada di Utara Perkotaan Sumedang.

Kabupaten Sumedang memiliki batas wilayah administratif sebagai berikut:

Sebelah Utara: Kabupaten Indramayu

Sebelah Selatan: Kabupaten Garut

Sebelah Barat: Kabupaten Bandung dan Kabupaten Subang

Sebelah Timur: Kabupaten Majalengka

Kecamatan paling luas wilayahnya adalah Kecamatan Buahdua dan yang paling kecil luas wilayahnya adalah Kecamatan Cisarua.

Peta Administratif Kabupaten Sumedang

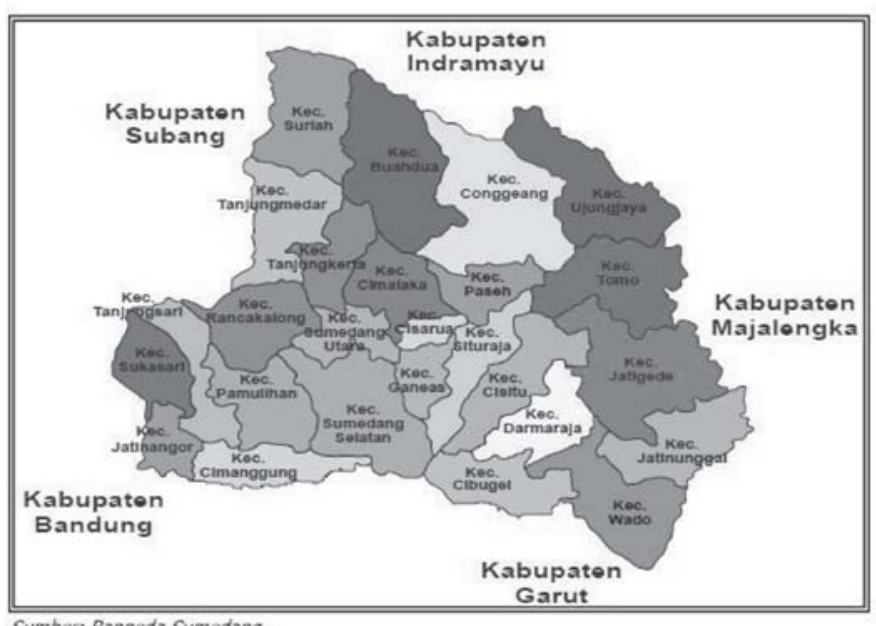

Sumber: Bappeda Sumedang

Sumber: www.sumedangkab.go.id/à tgl diakses 11 April 2012 